\section{Treatment of primary cutaneous anaplastic large cell lymphoma with superficial X-rays}

\author{
Malene E. Jepsen, ${ }^{1}$ Robert Gniadecki ${ }^{1,2}$ \\ 'Department of Dermatology, Bispebjerg \\ Hospital; ${ }^{2}$ Faculty of Health Sciences, \\ Copenhagen University, Denmark
}

\begin{abstract}
The optimal radiation schedule for primary cutaneous anaplastic lymphoma (PCALCL) has not been investigated. We report here satisfactory outcomes of low-dose (16-20 Gy, 3-5 fractions), superficial X-ray radiation $(40-50 \mathrm{kV})$ in a series of 10 patients with PCALCL. Only 1 patient developed a local relapse during the median observation time of 25 months; complete remission was recorded in the other patients. This observation indicates that superficial, low dose X-ray therapy may provide a cost-effective alternative to the traditional 35-45 Gy schedules.
\end{abstract}

\section{Introduction}

Primary cutaneous anaplastic large cell lymphoma (PCALCL) is a rare indolent cancer with a favorable prognosis and the 5-year specific disease survival of $90 \% .^{1-5}$ The patients often present with solitary or localized nodules or tumors, sometimes with ulceration. ${ }^{3}$ Treatment in most cases comprises surgery or radiotherapy, sometimes in combination. ${ }^{1,5-8}$ However, due to rarity of this disease the evi- dence for the efficacy of these modalities is very low. Here we report the excellent outcome of PCALCL treatment with superficial radiotherapy in a small cohort of 11 patients.

\section{Materials and Methods}

Patients with the diagnosis PCALCL were identified from the clinical lymphoma registry in our institution between September 2007 and October 2014. Among 277 patients with cutaneous T-cell lymphomas, 36 patients had a CD30+ lymphoproliferative disorder, and of these 13 were registered as having PCALCL. We have excluded one patient had spontaneous remission before treatment, one patient died of other causes before the outcome of the radiation therapy was registered and one patient who received electron beam radiation therapy (40 Gy) to multiple tumors in the scalp. The remaining 11 patients (Table 1) were treated with superficial radiotherapy using Gulmay D3100 X-ray unit (Gulmay Ltd., Surrey, UK).

\section{Results}

The male:female ratio was 2.67:1 (8 men, 3 women) which is compatible with the 2-3:1 ratio reported in the literature. ${ }^{3}$ The median age at diagnosis was 62 years. The median-follow-up time after radiation therapy was 26 months. Five patients had an associated malignancy: lymphomatoid papulosis (LyP) or mycosis fungoides (MF).

The patients were treated with the dose 1620 Gy given in 3-5 daily fractions (40-50 kV). All patients were evaluated after 3 months when complete response was observed in $8 / 10$ patients and partial response (PR) in $3 / 10$
Correspondence: Robert Gniadecki, Department of Dermatology, Bispebjerg Hospital, Bispebjerg bakke 23, DK-2400 Copenhagen, Denmark.

E-mail: r.gniadecki@gmail.com

Key words: radiotherapy, cutaneous lymphoma.

Contributions: the authors contributed equally.

Conflict of interest: the authors declare no potential conflict of interest.

Received for publication: 25 February 2014. Accepted for publication: 25 February 2014.

This work is licensed under a Creative Commons Attribution NonCommercial 3.0 License (CC BYNC 3.0).

(C)Copyright M.E. Jepsen and R. Gniadecki, 2015 Licensee PAGEPress, Italy

Dermatology Reports 2015; 7:5888

doi:10.4081/dr.2015.5888

patients (in patient 1 one of the tumors had a CR and one tumor had a PR). On a long-term observation one patient (Patient 9) had a local relapse and Patient 1 progressed and developed new lesions (but not within the irradiated site). No adverse effects were registered except for local hyperpigmentation and mild scarring within the irradiated site.

\section{Discussion and Conclusions}

Our data document satisfactory effect of superficial X-ray treatment of PCALCL tumors, using the doses 16-20 Gy and photon energy $40-50 \mathrm{kV}$. Theoretically, $50 \%$ of the radiation of this energy is absorbed within the most superficial $10 \mathrm{~mm}$ of the skin, ${ }^{9}$ which is less that the estimated thickness of some tumors.

Table 1. Patients' characteristics, treatments and outcomes.

\begin{tabular}{|c|c|c|c|c|c|c|c|c|c|c|c|}
\hline Patient & Sex & $\begin{array}{c}\text { Age at } \\
\text { diagnosis }\end{array}$ & $\begin{array}{c}\text { Clinical } \\
\text { s lesion(s) }\end{array}$ & $\begin{array}{c}\text { Size of } \\
\text { lesions, } \mathrm{cm}\end{array}$ & Location & $\begin{array}{l}\text { Secondary } \\
\text { lymphoma }\end{array}$ & $\begin{array}{l}\text { Radiation } \\
\text { dose }\end{array}$ & $\begin{array}{c}\text { Response at } 3 \\
\text { months }\end{array}$ & $\begin{array}{l}\text { Follow-up, } \\
\text { months }\end{array}$ & Relapse & Follow up \\
\hline 1 & M & 46 & 2 tumors & 3 & Left thigh and crus & - & 50 kV 4 Gyx 5 & $\mathrm{CR}+\mathrm{PR}$ (crus) & 56 & Local & PD \\
\hline 2 & $\mathrm{~F}$ & 35 & 1 tumor & 2.5 & Left crus & Lyp & 50 kV 6 Gyx3 & CR & 85 & New & CR \\
\hline 3 & M & 78 & 1 tumor & 1.5 & Right forearm & Lyp & 50 kV 4 Gyx5 & CR & 13 & None & CR \\
\hline 4 & M & 70 & Multiple tumo & rs $35 \times 20$ & Upper back & - & 50 kV4 Gyx5 & CR & 41 & None & CR \\
\hline 5 & M & 72 & 1 tumor & $2 \times 0.5$ & Right flank & - & 40 kV 4 Gyx4 & CR & 5 & None & CR \\
\hline 6 & $\mathrm{~F}$ & 65 & 1 plaque & $2 \times 3$ & Behind right ear & - & 40kV 4 Gyx5 & CR & 14 & None & CR \\
\hline 7 & $\mathrm{~F}$ & 48 & 3 tumors & $7 \times 5,5 \times 5.5,1.5$ & $\begin{array}{l}\text { Left upper arm, } \\
\text { right foot, } \\
\text { left first finger }\end{array}$ & $\mathrm{MF}$ & 50 kV 4 Gyx5 & PR & 13 & None & CR \\
\hline 8 & M & 67 & 1 tumor & $4 \times 3 \times 0.5$ & Left foot & - & $50 \mathrm{kV} 4 \mathrm{Gyx} 5$ & CR & 11 & New & CR \\
\hline 9 & M & 68 & 1 plaque & $10,3.5$ & Right calf, left hand & Lyp & 50 kV 4Gyx5 & PR & 8 & None & PR \\
\hline 10 & M & 78 & 1 tumor & 1.5 & Right upper arm & Lyp, MF & 40kV 4 Gyx5 & $\mathrm{CR}$ & 6 & None & CR \\
\hline
\end{tabular}

LyP, lymphomatoid papulosis; MF, mycosis fungoides; CR, complete response; $\mathrm{PR}$, partial response; $\mathrm{PD}$, progressive disease 
Nevertheless, the clinical outcome of the superficial therapy has been excellent with 90\% long-term CR. This indicates the high radio-sensitivity of PCALCL and possibly involvement of secondary anti-tumor mechanism such as bystander effect. ${ }^{10}$

Studies reporting outcome of radiotherapy in PCALCL are scarce.- ${ }^{2-5,7,10}$ The Yale Center records from 2008 is the only study involving radiation therapy exclusively using the dose of 34-44 Gy given in 2-Gy fractions. ${ }^{7}$ All eight reported patients achieved CR after 12 months median-follow-up. We propose here that the number of fractions and total radiation dose can be reduced to $16-20 \mathrm{~Gy}$, without a significant loss of long-term efficacy. The modified, low-dose schedule can be delivered as superficial radiotherapy which is more cost-effective and will probably reduce the risk of sideeffects.

\section{References}

1. Kadin ME. Current management of pri- mary cutaneous CD30+ T-cell lymphoproliferative disorders. Oncology 2009;23: 1158-64.

2. Benner MF, Willemze R. Applicability and prognostic value of the new TNM classification system in 135 patients with primary cutaneous anaplastic large cell lymphoma. Arch Dermatol 2009;145:1399-404.

3. Willemze R, Jaffe ES, Burg G, et al. WHOEORTC classification for cutaneous lymphomas. Blood 2005;105:3768-85.

4. Woo DK, Jones CR, Vanoli-Storz MN, et al. Prognostic factors in primary cutaneous anaplastic large cell lymphoma: characterization of clinical subset with worse outcome. Arch Dermatol 2009;145:667-74.

5. Booken N, Goerdt S, Klemke CD. Clinical spectrum of primary cutaneous CD30-positive anaplastic large cell lymphoma: an analysis of the Mannheim Cutaneous Lymphoma Registry. J Dtsch Dermatol Ges 2012;10:331-9.

6. Willemze R, Hodak E, Zinzani PL, et al. Primary cutaneous lymphomas: ESMO Clinical Practice Guidelines for diagnosis, treatment and follow-up. Ann Oncol
2013;24:149-54.

7. Yu JB, McNiff JM, Lund MW, Wilson LD. Treatment of primary cutaneous CD30+ anaplastic large-cell lymphoma with radiation therapy. Int $\mathrm{J}$ Radiat Oncol Biol Physics 2008;70:1542-5.

8. Kempf W, Pfaltz K, Vermeer $\mathrm{MH}$, et al. EORTC, ISCL, and USCLC consensus recommendations for the treatment of primary cutaneous CD30-positive lymphoproliferative disorders: lymphomatoid papulosis and primary cutaneous anaplastic large-cell lymphoma. Blood 2011;118:402435 .

9. Goldschmidt H, Panizzon RG. Modern dermatologic radiation therapy. New York: Springer-Verlag; 1991.

10. Nagasawa H, Little JB. Induction of sister chromatid exchanges by extremely low doses of alpha-particles. Cancer Res 1992;52:6394-6. 